\title{
Ten Seasons of the Football Banning Order: Police Officer Narratives on the Operation of Banning Orders and the Impact on the Behaviour of 'Risk Supporters'.
}

\section{Abstract}

The Football Banning Order was implemented under the Football (Disorder) Act (2000) to target 'risk' supporters where the supporter had (a) previously been involved in football-related disorder and (b) was likely to be involved in future disorder ${ }^{1}$. Although viewed by the government of the day as a necessary tool to tackle football hooliganism, it was criticised by opponents as draconian due to the restrictive conditions that could be imposed via civil process (on complaint) where no criminal conviction needed to be secured. Despite these ethical concerns, little research has considered how those responsible for the operation of the orders identify and target 'risk' supporters or the impact orders have on the behaviour of risk supporters. This paper aims to redress this gap in the research by presenting the findings of a number of interviews with police officers responsible for the operation of banning orders. The findings show police officers construct narratives that emphasise the need to control risk supporters and suggest banning orders have worked to serve this function. However, closer analysis of the data suggests that the number of banning orders implemented is partially generated by pressure to deliver targets and a desire of officers to justify and preserve their roles. This raises questions about the extent to which pressures to ensure banning orders are issued outweigh any ethical concerns over the use of the legislation.

\section{Introduction}

This paper considers the operation of football banning orders and how police officers responsible for pursuing such orders perceive them to impact on the behaviour of 'risk supporters' ${ }^{2}$ within the context of domestic football in England. The Football Banning Order (FBO) was legislated for in the 2000 Football (Disorder) Act (Home Office, 2000). This extended legislative powers designed to tackle hooliganism at home and abroad that were perceived to be failing. Previous to the FBO, the 'exclusion' order and the 'restriction' order had been used to ban convicted supporters from football matches at home and abroad. However, as a conviction was

\footnotetext{
${ }^{1}$ Throughout this paper the terms 'disorder' and 'violence' are used interchangeably.

2 'Risk supporter' is the official label given to football hooligans. Please see the discussion of the term presented later in this paper.
} 
required before restrictions could be imposed, often such orders could not be imposed on those commonly thought to be responsible for the violence (James \& Pearson, 2006). Therefore, following disorder involving England supporters at Euro 2000 in Belgium and the Netherlands, police powers were extended in the form of the civil banning order (orders on complaint). Under the legislation Chief Constables could apply for an FBO to be imposed 'on complaint' via civil process where two conditions were satisfied. First, the court had to be satisfied that the person who is the subject of the complaint had at any time caused or contributed to any violence or disorder $^{3}$ in the United Kingdom or elsewhere (Section 14b, Football (Disorder) Act, 2000). Second, there were reasonable grounds to believe that making a banning order would help to prevent violence or disorder at or in connection with any regulated football matches (Section 14b, Football Disorder Act, 2000). Where the court is satisfied these conditions are met, a civil order can be imposed for a period of up to three years (a banning order on conviction can be imposed for up to ten years). As part of the conditions attached to the order individuals can be excluded from a restricted zone around football stadiums for specific periods of time on match days and required to surrender passports up to five days before England play matches abroad (CPS, 2005).

The FBO has been labelled as being 'moral panic' legislation (Frosdick \& Marsh, 2005; Moss, 2009) and part of a growing trend in the use of preventative measures ${ }^{4}$ based upon 'actuarial' or 'risk-based' strategies that target populations 'deemed to pose a threat' (Zedner, 2009:81). Such approaches have been criticised as they bypass traditional values of due-process and offer quick-fix political responses where traditional values such as the presumption of innocence, proof beyond reasonable doubt and the proportionality of punishment are seen as little more than legal luxuries (Ignatieff, 2004). As Moss (2009) notes, the legislation in relation to Football Banning Orders can be described as 'hybrid' in that it operates through parallel systems of justice: the orders can be imposed via civil process and on a defendant not convicted of an offence, but breach of the conditions of the order results in a criminal justice sanction. Stott \& Pearson (2006) also question whether the restrictions that can be imposed are proportionate to the end goal of preventing football-related violence. Key to the debate on proportionality was a ruling made by the Court of Appeal to a civil liberties challenge to the Football (Disorder) Act 2000 made by two 'risk'

\footnotetext{
${ }^{3}$ Under section $14 \mathrm{c}$ of the Football Disorder Act, violence and disorder includes "threatening violence", and using racist, abusive w ords or "displaying w riting or any other thing which is threatening, abusive or insulting.

${ }^{4}$ Other examples of such orders include both the anti-social behaviour order (Asbo) and control orders for terrorist suspects.
} 
supporters in 2000 (see Pearson, 2002). In this test case, Gough and Smith ${ }^{5}$ challenged the application made to impose a civil banning order on them, claiming the conditions were in breach of their human rights. In this case, The Court of Appeal used the de Freitis test of proportionality to consider whether (i) the prevention of football violence by English fans abroad was sufficiently important to justify limiting a fundamental right of EU nationals to leave their territory; (ii) the measures designed to meet the legislative objective (the prevention of football violence abroad) were rationally connected to it; and (iii) the means used to impair the right to freedom were no more than necessary to achieve the objective (Stott \& Pearson, 2006: 6). In this case, the challenge made by Gough and Smith was unsuccessful and this paved the way for the widespread use of the FBO. Pearson (2002) makes two criticisms of the ruling. First, he draws attention to the fact that the Court of Appeal concluded an FBO should only be imposed where there is 'an exacting standard of proof that will, in practice, be hard to distinguish from the criminal standard' (Pearson 2002: 96). He goes on to argue that this proposed 'quasi-criminal' burden of proof for banning orders appears to contradict the original rationale for the introduction of the $2000 \mathrm{Act}$ (that there was not sufficient evidence to charge those suspected of involvement in football-related disorder). Second, he is critical of the reluctance of the Court of Appeal to apply key human rights principles to football supporters stating that:

It must be a matter of concern that the Court of Appeal is unwilling to consider applying key principles of the Treaty of the European Union, the European Convention of Human Rights and the rule of law in cases where the accused happens to be suspected of an offence committed in the context of a football match. (Pearson, 2002: 101)

Despite concerns over human rights issues, little research has considered how football supporters are targeted for banning orders and how such orders impact upon disorder. This is somewhat surprising as in November 2010 a total of 3,248 orders were in place in England and Wales and this is now a key part of the strategy to combat football hooliganism (Hamilton-Smith, Bradford, Hopkins, Kurland, Lightowler, McArdle \& Tilley, 2011). In relation to the operation of the FBO, James \& Pearson (2006) evaluated the application process in place for the imposition of an FBO by conducting court-based observations. They highlighted that it was common for Magistrates to accept evidence that appeared to be 'guilt by association' rather than exacting a standard of criminal proof as recommended in the Gough \& Smith

\footnotetext{
${ }^{5}$ Police intelligence suggested Gough and Smith w ere part of the Derby County hooligan firm 'The Derby Lunatic Fringe'.
} 
ruling and in some circumstances, there was an obsession with compiling evidence for profiles to secure civil FBOs, 'which could be curtailing opportunities for proffering criminal charges' (James \& Pearson; 2006: 528).

In addition to the work of James and Pearson (2006), a limited body of work has considered the impact of the FBO on the prevention of football related disorder. In their evaluation of the impact of the FBO on disorder at Euro 2004, Stott \& Pearson (2006) argue that the order had little impact on the prevention of disorder and this raised questions over branch (ii) of the proportionality test used in Gough \& Smith appeal. They noted that although over 2,000 banning orders were in place before Euro 2004, there was still some serious rioting involving England supporters. They concluded the main reason for this is because disorder involving England fans are commonly 'crowd events' triggered by heavy-handed policing, rather though planned engagement between rival hooligan firms. In these cases, the actions of the police serve to antagonise supporters and lead to an escalation of relatively low level disorder into serious rioting. In contrast where 'low-profile public-management' styles of policing are used there is greater fan acceptance of the legitimacy of the police and as a consequence, no large-spread rioting (also see, Stott, Hoggett and Pearson (2012) for an overview of the use of such policing models in relation to crowd management in the context of domestic football). Despite the claims of Stott and Pearson, some evidence suggests that the police place a high value on the FBO as a strategy to manage disorder. In their analysis of interviews with Football Intelligence Officers at three football clubs, Stead \& Rookwood (2007) report respondents thought FBO's were largely responsible for the break-up of hooligan firms and the decline in levels of disorder in and around football stadiums since 2000 . The findings in Stead \& Rookwood (2007) come as little surprise. Since the inception of the FBO a number of claims have been made about the impact of the orders; none more so than the Home Office website, where it is stated that in the region of 92 per cent of individuals whose orders have expired are 'assessed by police as no longer posing a risk of football disorder' (Home Office, 2012).

Despite the ethical concerns expressed over the use of the banning order, little research has considered how police officers responsible for the operation of orders target risk supporters and how orders are perceived to impact on the behaviour of those supporters. This paper aims to add to the research by presenting the findings of a number of interviews with police officers responsible for the policing of football. First, an outline of the methods used to collect the data and their limitations is 
presented. Second, consideration is given to officer perceptions of the problem of football-related disorder and how risk supporters are targeted. Third, findings relating to officer perceptions of the impact of banning orders are presented. Finally, some conclusions are drawn that suggest officers develop narratives that construct footballrelated disorder as an issue that can be dealt with through the use of banning orders. However, it is argued the widespread implementation of orders is not entirely driven by crime control concerns, but also through an interest in achieving targets necessary to ensure the survival of the banning order industry.

\section{Method}

The primary source of data presented in this paper are semi-structured interviews ${ }^{6}$ with a number of Match Commanders, Football Intelligence Officers and Force Banning Officers across seven areas that policed 12 football clubs in England (a brief description of each area and the number of banning orders monitored in the 2010-11 season is given in Table $1^{7}$ ). In order to highlight trends in the use of banning orders and the relationship between banning orders issued and arrests, data on banning orders issued since 2001, attendances at football matches and arrests within a 24 hour period of all football league matches since 1992-93 were also collected from the Home Office.

The semi-structured interviews were used to elicit detailed accounts about the operation of banning orders and observations in relation to the behaviour of risk supporters from police officers responsible for the strategic management of football and those 'working on the ground'. Initial contact in three of the areas (1, 2 and 3) was made via the UK Football Policing Unit (UKFPU). Officers in these three areas then provided contact details of relevant officers in areas 4, 5, 6, and 7. In all of the areas, football hooliganism had been a significant problem throughout the 1970's and 1980's and there had been ongoing problems with 'risk' supporters since. In each area a request was made to interview an officer responsible for managing the policing of football (Match Commander), an officer responsible for collection of intelligence in relation to football (Football Intelligence Officer) and the officer

\footnotetext{
${ }^{6}$ Interview s were originally conducted in four areas as part of an evaluation of the implementation of Banning Orders in Scotland (see Hamilton-Smith et al., 2011). In order to increase the sample size, additional interviews were conducted in three areas after the evaluation w as completed.

${ }^{7}$ The interview s w ere conducted betw een October 2010 and June 2011.
} 
responsible for getting banning orders to court (Force Banning Officer). In total, five Match Commanders were interviewed; six Football Intelligence Officers and four Force Banning Officers. Each interview followed the same format in that respondents were asked to:

- Describe their roles and responsibilities;

- Outline the football banning order legislation and any concerns they had in relation to its operation;

- Describe the nature and extent of football hooliganism in relation to the football club(s) they police;

- Outline the process for obtaining banning orders;

- Describe any evidence they had in relation to impact of the orders and if changes supporter behaviours had been observed as a result of the order.

All of the interviews were taped recorded, transcribed and analysed by coding data into specific themes or categories. This method produced detailed and candid accounts from police officers, though some caution needs to be expressed in relation to the inferences that can be made from these data. Firstly, interviews were only conducted in seven police areas ${ }^{8}$ covering 11 football league clubs (12\% of all 92 league clubs) and one non-league club. Therefore, caution has to be expressed over the generalisability of the findings. Secondly, the data are primarily based upon the perceptions of officers. Therefore, the findings cannot be taken as a fully objective account of the operation and effectiveness of orders. The accounts given in interview were from a policing perspective. However, what emerged from the interviews were clearly constructed narratives about the operation and impact of orders. These narratives are presented and discussed below.

\footnotetext{
${ }^{8}$ Here 'areas' refers to either a BCU (Basic Command Unit) or force area. In some areas (i.e. 3, 4 \& 5) the officers w ere responsible for policing clubs in a force area, in some larger forces, officers policed specific clubs in a BCU (i.e. $1,2,6 \& 7)$.
} 
Table 1: Overview of the seven areas where interviews were completed

\begin{tabular}{|c|c|c|c|}
\hline & $\begin{array}{l}\text { Interview } \\
\text { Respondents }^{9}\end{array}$ & $\begin{array}{l}\text { Brief description of football clubs } \\
\text { policed }\end{array}$ & $\begin{array}{l}\text { Average number of } \\
\text { fBOs monitored per } \\
\text { season }\end{array}$ \\
\hline Area $1^{10}$ & $\begin{array}{l}\text {-Match Commander } \\
\text {-Football Intelligence } \\
\text { Officer }\end{array}$ & $\begin{array}{l}\text { One Premiership Club with average } \\
\text { attendances of over } 40,000 \text {; world- } \\
\text { wide fan base. }\end{array}$ & Up to 100 \\
\hline Area 2 & $\begin{array}{l}\text {-Match Commander } \\
\text {-Football Intelligence } \\
\text { Officer }\end{array}$ & $\begin{array}{l}\text { One Premiership Club with average } \\
\text { attendances of over } 40,000 ; \text { world- } \\
\text { wide fan base. }\end{array}$ & Up to 50 \\
\hline Area 3 & $\begin{array}{l}\text {-Match Commander } \\
\text {-Football Intelligence } \\
\text { Officer } \\
\text {-Force Banning Officer }\end{array}$ & $\begin{array}{l}\text { Two Premiership Clubs with average } \\
\text { attendances over } 30,000 \text {. Both clubs } \\
\text { have moved between Premier League } \\
\text { and Championship in recent years. } \\
\text { Both have predominantly local fan } \\
\text { base. }\end{array}$ & Up to 100 \\
\hline Area 4 & -Force Banning Officer & $\begin{array}{l}\text { Championship Football Club with } \\
\text { average attendances of over } 25,000 \text {; } \\
\text { League Two club and a non-league } \\
\text { club. All have predominantly local fan } \\
\text { base. }\end{array}$ & $40-60$ \\
\hline Area 5 & $\begin{array}{l}\text {-Match Commander } \\
\text {-Football Intelligence } \\
\text { Officer } \\
\text {-Force Banning Officer }\end{array}$ & $\begin{array}{l}\text { Championship Football Club with } \\
\text { average attendances of over 15,000; } \\
\text { One League Two club. Both have } \\
\text { predominantly local fan base. }\end{array}$ & $70-90$ \\
\hline Area 6 & $\begin{array}{l}\text {-Match Commander } \\
\text {-Football Intelligence } \\
\text { Officer } \\
\text {-Force Banning Officer }\end{array}$ & $\begin{array}{l}\text { Championship Football Club with } \\
\text { average attendances of over } 20,000 \\
\text { and regular large away following. }\end{array}$ & $>100$ \\
\hline Area 7 & $\begin{array}{l}\text {-Football Intelligence } \\
\text { Officer }\end{array}$ & $\begin{array}{l}\text { Small Championship club with } \\
\text { attendances of } 10,000 \text { and League } \\
\text { Two club with large fan base. }\end{array}$ & $50-80$ \\
\hline
\end{tabular}

\section{Football banning orders and targeting 'risk supporters'}

The FBO was implemented at a time when serious hooligan encounters within football grounds had become rare (Williams, 2002: 40-1). After the Hillsborough disaster and the subsequent Taylor Report of 1989 (see Taylor, 1989, 1990), both football and football hooliganism appeared to move into a new phase. With the introduction of all-seated stadiums and the advent of the premier league in 1992-93 football was perceived to have launched into a new 'golden' era (Winter, 2009). As Frosdick \& Marsh, 2005 suggest, during the late 1980's football violence was also changing. Hooligan events were now more likely to occur at pubs, railway stations and on the streets before and after matches than in stadiums and the violence itself was commonly perceived to be well-organised and predominantly between hooligan 'firms' or 'casuals'. This displacement of violence has primarily been attributed to

\footnotetext{
9 Throughout respondents are referred to as MC (Match Commander); FBAN (Force Banning Officer) and FIO (Football Intelligence Officer).

${ }^{10}$ Due to the sensitive nature of the subject and the candid responses given by interview ees the areas and clubs policed have been anonymised.
} 
'securitisation' of football which has seen the introduction of all-seated stadiums, the implementation of situational crime prevention methods (such as CCTV) and strict ticketing policies around games (Frosdick \& Marsh, 2005).

Although initially implemented to tackle the problem of hooliganism in relation to the national England football team, all interviewees concurred that the FBO had become a key part of the strategy to tackle football violence domestically. The political impetus for this had been provided by the UK Football Policing Unit (UKFPU) ${ }^{11}$, which both provides funding for police areas to actively pursue banning orders and ensures that each area achieves a required number of orders per season. It was suggested by respondents that this political drive to pursue banning orders marked a shift in the way that football hooliganism has been managed, from one primarily based upon 'crowd management' and 'reaction', to an approach that has become more 'proactive' (MC, area 1). As one Match Commander succinctly stated:

Public order policing at big football matches was a Saturday pastime... football hooligans would turn out and there would be a bit of ruck, public order teams would deal with what was in front of them, then it was 'lets go back and all reconvene next week'. (MC, area 1)

A number of respondents did point out that the banning order is part of package of measures used to prevent football related disorder. Indeed, several respondents referred to other tactics used to deal with potential disorder. For example, one Match Commander spoke in detail about strategies that had been used in his area to manage crowds and 'deal with potential flashpoints' (MC, area 5) ${ }^{12}$, another spoke about the enforcement of street drinking bans around stadiums (MC, area 1) and across all areas reference was made to the effective segregation of supporters in and around stadiums. However, there was a consensus that the banning order had offered an additional tool, which helped the police to prevent disorder by being able to 'ban those who presented a persistent threat' (FIO, area 2). In all areas an emphasis was placed on the preventative function of orders; as the FIO in area 3 stated, '[the orders] exclude those elements intent on causing problems by excluding them from matches and from travelling abroad'. Although this preventative function was emphasised, the order also allowed risk supporters to be dealt with quickly as it gave 'police forces the power to begin to manage their hooligan problem without

\footnotetext{
${ }^{11}$ The UKFPU is managed by the Home Office.

12 For an overview of similar approaches please see Stott et al, 2012.
} 
having to pursue lengthy court cases that still might not achieve a conviction' (FIO, area 5).

Zedner (2009) asserts that one of the primary concerns in relation to such risk-based strategies is how risk-populations are targeted. As observed above, in relation to football hooliganism, the banning order is now perceived as a key part of the strategy to deal with groups of football supporters who are labelled by the police as 'risk supporters'. However, in interview, none of the respondents were able to provide a common definition of what constituted a risk supporter, although they were able to comment on the characteristics of this group. Risk supporters were colloquially referred to as 'casuals' and these were seen as groups of supporters, organised into hooligan 'firms' who are commonly identified by their causal style of clothing which include designer labels such as Stone Island, Burberry and Henry Lloyd (hence the name 'casuals'). These firms attach themselves to specific clubs and they often have names to give them a collective identify, such as 'The County Road Cutters' (Everton), 'The Bastard Squad' (Chesterfield) and 'The 657's' (Portsmouth). According to the respondents, this 'distinctive dress style and the way the casuals might plan and seek out violence with other rival risk supporters makes them easier to distinguish from ordinary supporters' (FBAN, area 4). Therefore term 'risk' was generically applied to supporters thought to be involved in hooligan firms and regularly involved in violence:

they're not just Mr Fred Bloggs who's just been arrested for swearing at a football match, they are actually connected to a football hooligan element. (FBAN, area 4)

In order to pursue a civil banning order ${ }^{13}$, intelligence officers or 'hooligan spotters' identify the risk supporters and banning officers then collate the evidence necessary to secure an order in court. The hooligan spotters identify individuals through eyewitness observations and CCTV footage of gatherings of risk supporters and specific incidents. In most cases, association with other known risk supporters and being in close proximity to disorder were enough to create sufficient police interest for an intelligence profile to be compiled. As one respondent said:

We mainly are watching the evidence gathering footage from the games and we'll pick up on an individual and then watch out for them on another video, and if they're still hanging around with their group then they'll get targeted. (FIO, area 6)

\footnotetext{
13 Automatic bans can be made through the courts on those convicted of a football-related offence (14a applications). Therefore intelligence gathering is not required in relation those convicted.
} 
In all areas, officers stated that evidence for an FBO is gathered by building an intelligence-led profile (or evidence dossier) on each risk supporter suspected of involvement in hooligan activities. Once a target is identified, any known intelligence on that person or records of previous criminal involvement, such as convictions for violence (football or non-football related), would be collected. The primary purpose of this initial intelligence gathering and surveillance is to satisfy the condition specified in the legislation, 'that the person who is the subject of the complaint has at any time caused or contributed to any violence or disorder in the United Kingdom or elsewhere' (Section 14b, Football (Disorder) Act, 2000). Once an intelligence package is opened this would be updated as and when new intelligence emerged in relation to the target. These updates might include information about when and where the target was spotted, who they were associating with and any photographic evidence of gatherings with other risk supporters and encounters with rivals. Most of the areas were keen to emphasise that large intelligence-led dossiers on subjects for banning orders were compiled that provided 'substantial' evidence of previous involvement in violence and disorder. As MC 1 stated 'it is important to gather detailed evidence in relation to the activities of risk supporters' as in most cases an evidential standard close to evidential proof admissible in court had to be gathered. However, all of the banning officers mentioned that the point at which there was 'enough' evidence to get a civil banning order was not always clear. In one area it was remarked that the 'civil process was something that is new to the police' (MC, area 6 ) and as a result there was a heavy reliance on using police legal teams for advice about the quality of evidence required to obtain a banning order.

However, there was some evidence of variation from area to area in terms of the standard of evidence the courts routinely accepted. Indeed, one FIO commented on the 'thin intelligence packages being accepted in a neighbouring force area' (FIO, area 7) and another on the 'ease' at which one Metropolitan force was able to get civil orders through the courts (MC, area 1). This evidence suggests that, on occasion, banning orders might be issued to supporters who could not be considered to be part of a risk group. Indeed, in four areas $(4,5,6,7)$ respondents suggested the standard of evidence required to obtain civil orders can vary according to the context in which disorder takes place and 'high profile' incidents were mentioned where there had been pressure to pursue banning orders. For example, in one area a pitch invasion by several hundred supporters and in another, in incident in an Eastern 
European country after a UEFA cup game led to pressure to pursue banning orders against people who had no previous record of involvement with the risk group.

It was totally out of character for a lot of them, normal supporters, never been involved in trouble before, they got involved on the day and all got banning orders. (FIO, area 7)

In [European place name] there was really bad violence and we got a huge number of bans out of that one. Some of then had never come up before and were literally banned because of the one match. It was more serious because it was abroad; we had no trouble with the courts in getting bans for that one. (FIO, area 5)

This evidence not only runs contrary to the requirements of the legislation, but also suggests James and Pearson's (2006) observation that supporters can be perceived as 'guilty by association' is correct. Indeed, in the examples provided above, both police forces attempted to pursue bans for as many supporters as possible who were in the vicinity of the incidents, regardless of whether they were known to be risk supporters or not. This suggests rather than simply use banning orders to target risk supporters, opportunities were also taken to increase the numbers of orders issued whenever possible. Therefore, another important factor appears to be at play here. Most police Force Banning Officer posts are funded by the UKFPU and targets are set in relation to the number of civil orders that have to be achieved per season. Therefore, there is pressure on police officers to achieve targets. This point is emphasised through secondary analysis of data relating to banning orders issued per club. Table 2 compares the number of banning orders in the 2008-09 football season for the ten clubs with the highest average attendances in that season compared to those with the highest numbers of banning orders in place. The numbers of banning orders are expressed as a rate per 1,000 spectators. This shows that none of the clubs with the highest attendances had a banning order rate of over 2 per 1,000. However, ten lower league clubs had a banning order rate of over 6 per 1,000. All of these clubs (with the exception of Cardiff City \& Portsmouth) played in the bottom two divisions of English football during that season. 
Table 2: Targeting of Banning Orders: Rate of orders by average attendance figures (season 2008 to 2009)

\begin{tabular}{|c|c|c|c|c|c|c|c|}
\hline \multicolumn{4}{|c|}{ Top ten average attendances } & \multicolumn{4}{|c|}{ Top ten banning order rate } \\
\hline Team & $\begin{array}{l}\text { Average } \\
\text { attendance }\end{array}$ & $\begin{array}{l}\text { FOs } \\
\text { in } \\
\text { place }\end{array}$ & $\begin{array}{l}\text { BO rate } \\
\text { per } \\
1,000\end{array}$ & Team & $\begin{array}{l}\text { Average } \\
\text { attendance }\end{array}$ & $\begin{array}{l}\text { FBOs } \\
\text { in } \\
\text { place }\end{array}$ & $\begin{array}{l}\text { BO rate } \\
\text { per } 1,000\end{array}$ \\
\hline $\begin{array}{l}\text { Manchester } \\
\text { United }(P)\end{array}$ & 75304 & 74 & 1.0 & Millwall (1) & 8940 & 110 & 12.3 \\
\hline Arsenal $(P)$ & 60039 & 44 & 0.7 & Chesterfield (2) & 3448 & 36 & 10.4 \\
\hline $\begin{array}{l}\text { Newcastle } \\
\text { United }(P)\end{array}$ & 48749 & 99 & 2.0 & $\begin{array}{l}\text { GrimsbyTown } \\
\text { (2) }\end{array}$ & 4474 & 41 & 9.2 \\
\hline Liverpool (P) & 43625 & 78 & 1.8 & $\begin{array}{l}\text { Aldershot Town } \\
\text { (2) }\end{array}$ & 3276 & 28 & 8.5 \\
\hline $\begin{array}{l}\text { Manchester } \\
\text { City }(P)\end{array}$ & 42900 & 53 & 1.2 & Darlington (2) & 2931 & 23 & 7.8 \\
\hline Chelsea $(P)$ & 41588 & 63 & 1.5 & Cardiff City (C) & 18043 & 124 & 6.9 \\
\hline $\begin{array}{l}\text { Sunderland } \\
(P)\end{array}$ & 40163 & 67 & 1.7 & Leeds United (1) & 23813 & 162 & 6.8 \\
\hline $\begin{array}{l}\text { Aston Villa } \\
(\mathrm{P})\end{array}$ & 39811 & 79 & 2.0 & $\begin{array}{l}\text { Tranmere Rovers } \\
\text { (1) }\end{array}$ & 6575 & 43 & 6.5 \\
\hline $\begin{array}{l}\text { Tottenham } \\
\text { Hotspur }(\mathrm{P})\end{array}$ & 35928 & 39 & 1.1 & $\begin{array}{l}\text { Hartlepool United } \\
\text { (1) }\end{array}$ & 3834 & 25 & 6.5 \\
\hline Everton $(P)$ & 35662 & 56 & 1.6 & Rochdale (2) & 3222 & 20 & 6.2 \\
\hline
\end{tabular}

It is, of course, unlikely that there will be a direct correlation between average attendances and the numbers of risk supporters who receive a banning order. Some football clubs (such as Millwall, Leeds and Cardiff City) are thought to have large hooligan firms, which translates into high rates of banning orders. However, it is surprising that Grimsby Town had 41 orders in place, compared to 39 for Tottenham Hotspur as it would appear unlikely that Grimsby has a larger contingent of risk supporters than Tottenham. This suggests that although the figures might partially be risk-driven (for example, at Millwall, Leeds and Cardiff), they are also targetdriven. As one respondent said 'if we don't reach the target set by the UKFPU, we will cause a problem and we won't be here' (FBAN, area 3).

\section{Perceptions of impact: banning orders and the behaviour of risk supporters.}

Two clear narratives were observed in relation to the impact of the orders on the behaviour risk supporters. Firstly, there was a view that banning orders impact through a process of specific and general deterrence. Secondly, despite the apparent success of banning orders, it was thought risk supporters needed to be closely monitored as the most determined hooligans have changed spatial and temporal dynamics of their behaviour in order to avoid police surveillance. These 
narratives were constructed through a variety of means: the official Home Office view on the efficacy of banning orders, the views of colleagues and experience 'on the job'. These narratives are explored below.

When asked about the efficacy of banning orders, many respondents were quick to point to the 'official' Home Office view that football banning orders have been 'highly successful' (Home Office, 2011). Indeed, The Home Office claims that by the time an order expires, the behaviour of risk supporters 'has usually transformed' and that 'in 92 per cent of cases, the person is felt by the police to no longer pose a risk' (Home Office, 2011). None of the respondents were able to comment on how the Home Office arrive at these figures, and indeed, there is no explanation in the Home Office literature as to how these figures are derived. However, many officers viewed these figures as proof of efficacy. Some officers also pointed to the compliance of risk supporters in observing the conditions of their ban (such as handing in of passports before international fixtures) as proof of effectiveness (areas 1, 3 and 5). However, none of the respondents were able to provide any empirical proof of the proportion of risk supporters on bans who had stayed away from football-related disorder over the long-term and further to this, there was no empirical evidence available in relation to any reduction in disorder associated with football matches. Further to this, the authors of this paper analysed Home Office data on the numbers of arrests in and around football matches and numbers of banning orders implemented to establish if a relationship existed between the two. Data were available in relation to the numbers of banning orders issued from the 2001-2002 season and these were compared to numbers of arrests made within a period of 24 hours either side of all football league matches in England \& Wales from the 1992-93 season (eight years before the 2000 Football Disorder Act) through to $2009 / 10^{14}$. These data are presented in Figure 1 and show that, in the eight years before the implementation of the order, the numbers of arrests at football matches ${ }^{15}$ fell rapidly from 4,588 in 199292 to 3,000 in 2001-2002. After implementation of the order in August 2001, one might expect to see arrests fall at an increased rate. However, despite the rapid implementation of banning orders from 687 in August 2001 to a peak of 3,387 in August 2006, the arrest rate continued to fall at the same pace. Therefore, the

\footnotetext{
${ }^{14}$ This covers all arrests designated in law under schedule 1 of the Football Spectators Act 1989 (as amended) reported by police to the Football Banning Orders Authority. This includes football specific offences (e.g. throw ing missiles in a stadium, pitch encroachment) and a wide range of generic criminal offences committed in connection with a football match.

15 The data here is for all arrests as arrest data for violence and disorder are not available prior to $2000 / 01$. Therefore, this includes violence and public disorder, missile throwing, racist chanting, pitch incursion, alcohol offences, ticket touting, carrying offensive w eapons and property offences.
} 
reduction in arrests at football matches seems to be part of a continuing long-term trend rather than an outcome of the imposition of the banning order.

Figure 1: The number of FBO's (on conviction \& civil) in place and the numbers of arrests for violence and disorder connected to football matches since 1992-93 season.

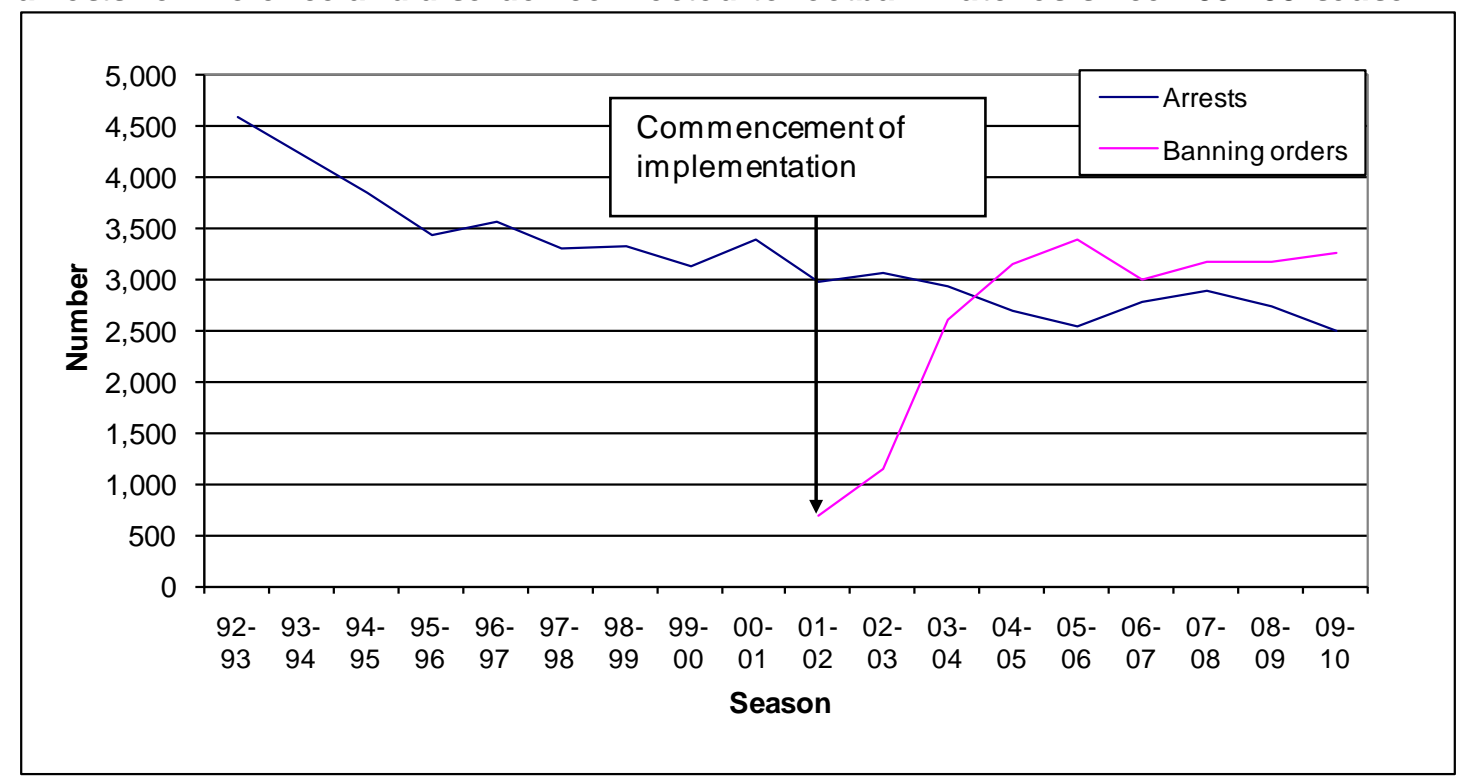

Of course, caution has to be made when using these indicators of impact. As Frosdick \& Marsh (2005) argue, arrests might not be a good indicator of the levels of activities by risk supporters for two reasons. Firstly, it can often be difficult to make large numbers of arrests when violence and disorder does occur and (secondly) disorder can often take place in locations unknown to the police. In interview, officers were asked to comment on the relationship between numbers of orders implemented and arrests in and around football stadiums. In general, they concurred with the view forwarded by Frosdick and Marsh that it can be difficult to make arrests in relation to the activities of risk supporters. However, this observation does raise some questions in relation to the claims officers make about the efficacy of banning orders. On the one hand, police officers claim banning orders work in controlling risk supporters, though also suggest disorder involving risk supporters can sometimes take place in locations unknown to them. If this is true, then potentially, many risk supporters with banning orders in place might still be involved in disorder, but in locations unknown to the police.

Although questions remain over the empirical proof, officers claimed that since the implementation of the banning order, they had seen changes in hooligan behaviour. 
The main narratives here emphasised that the banning order served a 'specific' and 'general' deterrence function. Hopkins Burke (2010:47) asserts that specific deterrence works when 'the apprehended and punished offender refrains from repeat offending because they realise they are certain to be caught and punished'. General deterrence works when the punishment of offenders by the state is 'seen to serve as an example to the general population who will be frightened into non-participation in criminal behaviour (Hopkins Burke, 2009:47). Across all areas, banning orders were thought to serve a specific deterrence function by targeting the population of hooligans labelled as the 'the hardcore element' (FIO, area 7) or those who were believed to be the leaders of firms and organising violence. For example, in area 2 the top five hooligans were targeted, in area 5 the top 20 and in as the FBAN in area 4 commented, 'we targeted our top boys'. Targeting the leaders of hooligan firms was believed to promote specific deterrence as hooligans realised that 'there's consequences beyond a glorified game of tick on a Saturday afternoon' (FIO, area 1). Indeed, it was suggested across all areas that the removal of leaders was critical in reducing the likelihood of organised violence. As one Intelligence Officer succinctly stated, 'take out the top five and the others don't know what to do, there are no movers and shakers amongst them' (FIO, area 7).

Although respondents suggested the break up of some hooligan groups could be attributed to the banning order, it was also thought the order had a general deterrence effect, which could be observed in the way the behaviour of many risk supporters had been modified. Officers suggested that 'non-participation in hooliganism' had not been driven by the threat of any criminal justice sanction, but by threatening risk supporters with exclusion from stadiums. Respondents recognised that for most risk supporters being denied that opportunity to follow their team has huge consequences. As one officer stated, 'most have been brought up and bred on football, taking that away from them is worse than prison' (FIO, area 7). To this extent, civil banning orders were therefore not only pursued as an alternative to 'long and expensive criminal investigations after the event' (FBAN, area 4) but were favoured over a criminal justice sanction. Indeed, the strong pursuit was thought to send out a message that 'the police were monitoring the behaviour of risk supporters, the bad behaviour of risk supporters has consequences and any risk supporter could be targeted next' (MC, area 1 ).

These findings suggest that although the legislation is justified as being 'preventative', police officers viewed the punitive function as key to any general 
deterrence effect. Indeed, the possibility of exclusion from stadiums was thought to have altered the behaviour of hooliganisms in two ways. Firstly, it was thought the 'knowledge about the orders and how we operate' (FIO, area 2) had led to risk supporters becoming more selective about which games to attend in order to reduce the likelihood of the police being able to build a profile on them. Thus, it was remarked that if hooligans suspect the police might be building a profile on them, 'they [the risk supporters] would 'disappear for six months' (FBAN, area 4). Therefore, 'turning out' or 'presenting' every week was thought to be too much of a risk to hooligans as this offered the police the opportunity to add information to evidential profiles on risk supporters.

The actual behaviour of the football risk group has changed and they don't do as much as ... they don't turn out every week at 60/70 strong because they know damn well that that's a tick in my box. They know how we work because they've had these files before, they've looked through their files, they know how it works. (FBAN, area 4)

Making risk supporters more selective as to when they turn out would, at face value, appear to endorse the view the order works to prevent 'the regular, weekly disorder we saw in the 1980's' (FIO, area 7). Indeed, respondents suggested that this actually made it easier to predict the games around which hooligan events might occur. It was stated that 'they [risk supporters] will always turn out for big games against local rivals or if a team with a big reputation for trouble come down' (FBAN, area 4) as 'their reputation depended on it' (FIO, area 1). Thus, predicting the games where trouble might occur was a relatively straight-forward exercise. However, there was a second impact of banning orders. For some risk supporters with banning orders in place, the desire to continue to be involved in disorder meant they would attempt to get around the spatial and temporal restrictions of their order by altering their behaviour. As the following excerpts suggest, the more determined risk supporters work around the conditions of their order:

like at Millwall there were a few there that they have time limits as well, so the time limit might have been two hours before the game. When they turned up at Millwall they turned up at 10 o'clock in the morning and the game were kicking off at three, so they'll work around their banning order. (FIO, area 4) 
They will congregate just outside the [pub name] pub, which falls just outside the exclusion area. They'll go just there to maintain that camaraderie, contact and visible presence. (FIO, area 5)

Although police officers acknowledged these forms of displacement, they did not view this as being a negative consequence of banning orders, but rather a product of the determination of some of the more 'hardcore' risk supporters to continue to engage in disorder. The FBAN in area 4 commented that as a consequence of the pursuit of banning orders in relation to two of the bigger football clubs in his area, risk supporters from these clubs (who remain fierce rivals) had often joined together to seek disorder by following a local non-league club where banning orders had not been so vigorously pursued. This not only suggested that some risk supporters were prepared to put traditional rivalries to one side in order to seek disorder, but also that the attraction or 'buzz' made some identify new venues for disorder. Indeed, the concept of the 'thrill of confrontation' or 'peak' experiences has been widely recognised in the literature on football violence generally (see for example, Finn, 1994; Kerr, 1994; Ayres and Treadwell, 2012) and, in interview, several officers commented on the desire of the risk group to 'seek a high from alcohol, taking cocaine and confrontation' (FBO, area 4). Alongside this it was also suggested that the identity and status that could also be achieved from being part of a hooligan group made it hard for some risk supporters to disassociate from other hooligans ${ }^{16}$.

it's being part of a football risk group, because being part of a football risk group you've got all them friends and when you drink out in town nobody come near you because I'm [part of the hooligan firm], you get your girls that want to go out with a football lad because they wear the designer gear and all that, a lot of people do in my opinion connect themselves to that. You've got your certain element that all they want to do is have a fight. I think there's more that just want to be that person with the Stone Island jumper on going around with 40 other lads and they're not touching you because you're one of the lads. (FBAN, area 6)

Therefore, the determination of some risk supporters to seek out confrontation would suggest the potential of the banning order to prevent disorder is somewhat limited. However, rather than conclude that the banning order had contributed to the malign

\footnotetext{
${ }^{16}$ This has also been w idely recognised in the research. See for example, Armstrong, (1998); Ayres and Treadwell, (2012).
} 
forms of displacement observed, respondents emphasised both the determination of risk supporters to seek out disorder and their disposition towards disorder as the major cause. One officer suggested that to a risk supporter, football violence was a 'normalised kind of behaviour within their cultural breeding' (MC, area 6). Indeed, most of the police officers interviewed had several years experience of policing football and remarked on the way that football not only attracts those wanting to seek disorder, but also reproduces violence: both by attracting new risk supporters and through the 'sons of risk supporters following in their father's footsteps' (FBAN, area 7). As the FBAN in area 3 remarked, 'We got [name of hooligan] and he was there, with his son at the front when it kicked off with Stoke'.

\section{Discussion and concluding comments}

The findings show that police officers construct narratives that present football banning orders in a favourable light and also justify the use of orders in order to prevent what they perceive as an ongoing problem. Indeed, the way that these narratives are constructed can be readily summarised by drawing on previous research that explores how individuals make sense of ethical issues in the workplace. For example, Soneshian, 2007 suggests that such issues are constructed and justified in a three stage process. Firstly, there is a process of 'issue construction' where individuals make sense of issues by constructing both individual and collective accounts that enable sense to be made of them. Secondly, there is a process of intuitive judgement where judgements are made and responses made to the issue. Finally, individuals then 'rationalise and justify their actions through socially constructed accounts' (Sonneshian, 2007: 1034). In relation to football banning orders, a similar process is observed in the accounts given by officers. Here narratives are presented that (1) construct the issue; (2) outline responses to the issue and (3) confirm of the impact of responses.

In relation to issue construction, police officers constructed the issue by distinguishing supporters perceived to be a risk from 'normal supporters'. Risk supporters are perceived to be different from 'normal supporters' both by the way they look (in terms of demeanour and dress) and their determination to seek out disorder. Even with the perceived decline of hooliganism in recent years, the risk group were viewed as a constant threat and in order to effectively manage this group, football banning orders were thought to be an appropriate response to the issue. This 
response meant the risk group could be effectively managed through the pursuit of civil orders, which negate the need for lengthy criminal trials. Theoretically, civil orders mean the risk group can be controlled more efficiently, though the use of the civil provision raises an ethical dilemma, which officers circumvent in two ways. Firstly, the response is justified by the requirement for evidence gathering that provides a high standard of proof of involvement in disorder. Secondly, officers emphasise the crime control function of the orders and how the orders appear to have worked to control the risk group. Therefore, through narratives that confirm the impact of the orders, concerns in relation to any ethical issues appear to be outweighed by the need to control the risk group and the belief the orders impact on behaviour. In relation to impact, the narrative emphasises the official Home Office view on effectiveness and draws on officer perceptions in relation to the specific and general deterrence function of the orders. Thus the orders are perceived to work through the specific targeting of risk supporters (in this case the leaders of hooligan firms) and this drives a general deterrence function as other risk supporters are aware the police have these powers to pursue banning orders. The only negative impact of the banning order is perceived to be the potential for spatial and temporal displacement of disorder. However, this negative impact is used to further justify the continued surveillance and management of supporters as police officers suggest this proves how determined some risk supporters are to engage in disorder. Therefore, this group need to be monitored and managed as closely as possible. Indeed, there was a consensus that as football generates the expectation of violence and thus attracts groups wanting to engage in violence, police management was a necessary part of a long term strategy to control risk supporters.

At face value one might perceive these narratives to simply reflect the concerns of officers in relation to the control of crime. Indeed, police offers welcomed the wider changes in the culture of crime control that allowed them to target risk supporters through the use of banning orders. However, the evidence also suggests the numbers of banning orders issued are not just generated through concerns over crime control. The growing trend to manage risk groups through the use of 'preventative' civil orders has also been mirrored by the growth in target and performance culture where funding for specific jobs is often dependent upon the achieving certain targets (O'Malley, 1996). Thus, the reliance of local police forces on external funding for banning officer posts appears to have helped create a target driven industry that needs to implement a specific number of banning orders to survive. Therefore, rather than serve a crime control function, the banning orders are 
also being used to ensure the survival of an industry through the widespread imposition of banning orders across all 92 football league clubs. Although police officers appear to be able to justify the use of orders, it is evident the desire to pursue orders also appears to have negative consequences. The claims that orders are only targeted at risk supporters where there is a 'a high standard of proof' of involvement in hooliganism runs counter to examples where orders have been issued for supporters with no history of violence who become involved in one-off crowd events. Indeed, the evidence also suggests that the standard of proof required for an order can vary from area to area and orders are more readily issued when disorder occurs with particular contexts (such as abroad). This indicates an unsatisfactory state of affairs exists where orders are not always issued in a consistent manner or targeted exclusively to risk supporters.

The primary limitation of this research is that data are only collected from police officers responsible for the targeting of banning orders. As one might expect, their narratives are favourable towards the use of banning orders. However, their accounts also highlight inconsistencies in how this risk-based approach operates and suggest that a culture driven by target setting can eclipse any ethical concerns. As Gray (2012) asserts, such risk-based approaches are 'an emerging field for managing the 'dangerous classes' (Gray, as cited in Goddard 2012: 2) and a way of expanding state power through the police, courts and prisons (Goddard, 2012: 3). This research suggests the police claim to manage the risk group by drawing distinctions between 'risk supporters' and non-risk supporters, and that they only use the powers given to them in order to control this risk group. However, the extent to which such civil orders are always targeted to risk supporters is questionable and concerns are raised that echo Pearson's assertions in relation to the human rights of football supporters (see Pearson, 2002). Of course, police officers tend to negate such ethical concerns by focusing on the perceived crime control impact of the orders. There is, however, a need for further research focusing upon on a sample of risk supporters with a banning order in place. This work would enable a more balanced view to be ascertained in relation to both the operation of the orders and their impact on behaviour. Indeed, such research would not only offer valuable insight in relation to the impact of football banning orders, but would also develop a greater understanding of how risk groups perceive such orders and contribute to the paucity of knowledge in relation to the operation and impact of preventative orders generally. 


\section{References}

Ayres, T. \& Treadwell, J. (2012) 'Bars, drugs and football thugs: Alcohol. Cocaine use and violence in the night time economy among English football firms'. Criminology \& Criminal Justice 12 (1): 83-101.

Armstrong, G. (1998) Football Hooliganism: Knowing the Score, Berg.

Crown Prosecution Service (2005) Guidance to Prosecutors and Managers Football Related Offences, www.cps.gov.uk/publications/prosecution/football_offences_guidance.html\#_05 [accessed 23/07/2011].

Evans, R. (2001) 'Call for contribution Costs of all policing football games'. Police Review, 24th August: 9.

Garland, D. (2001) The Culture of Control: Crime and Social Order in Contemporary Society. Oxford: Oxford University Press.

Goddard, T. (2012) 'Post-welfarist risk managers? Risk, crime prevention and the responsibilization of community-based organizations'. Theoretical Criminology $0(0)$ : 1-17.

Gough - vs - The Chief Constable of Derbyshire (2002) Court of Appeal, England and Wales, www.ipsofactoj.com/international/2002/Part13/int2002(13)-010.htm [accessed 22/07/2011].

Feeley, M. \& J. Simon (1994) 'Actuarial Justice: The Emerging New Criminal Law', pp. 173-201 in D. Nelken (ed.) The Futures of Criminology. London: Sage.

Finn, G. (1994) 'Football Violence- a societal psychological perspective', in R.

Giulianotti et al (eds) Football, Violence and Social Identity, pp. 90-127. London:

Routledge.

Frosdick, S. \& Marsh, P. (2005) Football Hooliganism. Cullompton: Willan Publishing. 
Hamilton-Smith, N., Bradford, B., Hopkins, M., Kurland, J., Lightowler, C., McArdle, D \& Tilley, N. (2011). An evaluation of football banning orders in Scotland. Scottish Government Social Research.

Home Office (2000) The Football (Disorder) Act, www.legislation.gov.uk/ukpga/2000/25/contents [accessed 24/04/2011].

Home Office (2005) Football (Disorder) Act 2000: Report to Parliament. London: HMSO.

Home Office (2011) Statistics on football-related arrests and banning orders: seasons 1992-93 to 2010-11, www.homeoffice.gov.uk/publications/crime/footballarrests-banning-orders [accessed 23/07/2011].

Hopkins-Burke, R. (2009) An Introduction to Criminological Theory, $3^{\text {rd }}$ Edition. Oxon: Willan.

Ignatieff, M. (2004) The Lesser Evil: Political Ethics in an Age of Terror, Edinburgh: Edinburgh University Press.

Kerr, J. (1994) Understanding Soccer Hooliganism. Buckingham: Open University Press.

Lord Justice Taylor (1989) Interim Report into the Hillsborough Stadium Disaster, HMSO, CMND 765

Lord Justice Taylor (1990) Final Report into the Hillsborough Stadium Disaster, HMSO

James, M. \& Pearson, G. (2006) 'Football Banning Orders: Analysing Their Use in Court', Journal of Criminal Law, 70 (6): 509-530.

Marsh, P, (1978) Aggro: The Illusion of Violence, London: Dent 
Marsh, P., Rosser, E., \& Harré, R. (1979) The Rules of Disorder. London:

Routledge.

Martinson, R. (1974). 'What works?-Questions and answers about prison reform'. Public Interest, 35: 22-54.

Moss, K. (2009) Security \& Liberty. Basingstoke: Palgrave.

O'Malley, P. (1996) 'Risk and Responsibility', in Barry, A., Osborne, T. and Rose, N. (eds) Foucault and Political Reason, Chicago, IL, University of Chicago Press.

Pearson, G. (2002) A Cure Worse than the Disease? Reflections on Gough and Smith v. Chief Constable of Derbyshire. Entertainment Law, Vol. 1, No. 2, 92-102.

Smith, R. (2005) 'The game's gone soft', The Guardian, Wednesday 6 April 2005.

Sohenshein, S. (2007) 'The Role of Construction, Intuition, and Justification in Responding to Ethical Issues at Work: The Sensemaking-Intuition Model', Academy of Management review, 32 (4): 1022-1040.

Stead, D. \& Rookwood, J. (2007) 'Responding to Football Disorder: Policing the British Fan'. Journal of Qualitative Research in Sports Studies. 1 (1): 33-41.

Stott, C. \& Pearson, G. (2006) 'Football Banning Orders, Proportionality \& Public Order Policing', Howard Journal of Criminal Justice. 45 (3): 241-254.

Stott, C \& Pearson, G. (2008) Football "Hooliganism", Policing and the War on the "English Disease". London: Pennant Books.

Stott, C., Hoggett, J. and Pearson, G. (2012) 'Keeping The Peace: Social Identity, Procedural Justice and the Policing of Crowd Events'. British Journal of Criminology. 52 (2): 381-399.

Williams, J. (2002) 'Who are you calling a hooligan?' in M. Perryman (ed.) Hooligan Wars: Causes and Effects of Football Violence, pp. 37-53. Edinburgh: Mainstream. 
Winter, H. (2009) English football enjoying new golden era despite global recession, www.telegraph.co.uk/sport/football/competitions/premier-league/5220343/Englishfootball-enjoying-new-golden-era-despite-global-recession.html [accessed 23/07/2011].

Zedner (L). (2009) Security. Oxon: Routledge. 